\title{
Melting the Iron Curtain: opportunities for public health collaboration through international joint ventures
}

\author{
George A Gellert, Sergei I Kaznady
}

Though dramatic events in the Soviet Union over the past five years have reshaped Western thinking on international relations and security, a revisioning of strategies for international public health collaboration with the Soviet Union has not occurred. A need for collaborative research and for improving exchange programmes with Western medical scientists has been recognised by Soviet physicians. ${ }^{1}$

Data from eastern Europe and the Soviet Union suggest that the rapidly declining health state of populations living behind the (former) Iron Curtain warrants international public health collaboration targeted at the socialist nations and the Soviet Union itself. ${ }^{23}$ The Soviet minister of health has, furthermore, called for a major restructuring of the health system, with a greater emphasis on prevention. ${ }^{4}$ These facts, in addition to the growing obsolescence of distinct domestic and international health sectors ${ }^{5}$ and the emergence of global interdependence in health, ${ }^{6}$ suggest new opportunities for international public health collaboration.

\section{Which model?}

As the Soviet Union recasts itself politically, economically, and socially a process of rigorous critical self examination is occurring. Soviets turn westward with an admiring eye on Western concepts and institutions such as democracy, government accountability, and free market economics, but which nation should act as a model for reform in public health?

It may be ill advised for the Soviets to discard all values that have been associated (at least rhetorically) with socialism. Abandoning the objective of universal access to health care in the movement to a market economy could be regressive. As a command economy is decentralised and privatisation is introduced it may be unwise to diminish the contributions of modern governments to health care infrastructure, medical research, and disease monitoring and prevention.

As an economic and military superpower the United States is understandably the object of much Soviet reform interest. The United States, however, continues to query the appropriate function of government in health care provision and worries about statistics such as its 37 million uninsured citizens or the quarter of Americans inadequately covered. ${ }^{78}$ Internationally the United States ranks 22nd in infant mortality and 13th in life expectancy at birth. ${ }^{9}$ These figures are arresting in view of the size of national health expenditures, which account for $11 \cdot 2 \%$ of the gross national product. ${ }^{10}$

Though recent political trends have ostensibly sought to reduce government's role in the lives of Americans, it is doubtful that the United States private sector alone could impact meaningfully on public health problems of the scope and magnitude confronting the nation. As in other aspects of policy Soviet health planners are faced with strategic choices in revising the Soviet health system, and few desirable or applicable models offer guidance.

\section{Western approaches to private-public collaboration in health.}

In the West private sector involvement in health usually takes the form of funding for research, health education and promotion activities, and delivery of clinical services. While often philanthropic, these health investments provide business interests with profit and publicity and demonstrate corporate concern for public welfare. In the United States the development of the commercial business sector and the public health sector has occurred independently and public-private collaboration in health has not been explored until quite recently.

Government-public sector contributions to United States health have become essential in certain settings (such as the care of the indigent, infirm, and aged) where private initiatives have been limited. Potential private sector contributions need not be exclusively material or fiscal but might include other resources, such as technical skills, strategic planning, and cost effective and efficient management. Inadequate use of private sector resources and initiative in public health has contributed to disturbing trends. Large proportions of the non-indigent population cannot utilise or underutilise health services because of financial constraints. ${ }^{11}$

Heavy reliance on public resources for providing clinical services to low income groups (often for preventable causes of morbidity) is growing as resources are increasingly constrained. ${ }^{12}$ Americans have not viewed government participation in medical care as the promotion of complete equity. ${ }^{13}$ Social philosophy has been directed towards improving opportunities rather than eliminating inequities, ${ }^{13}$ which are in the form of expensive, curative high technology rather than disease prevention and health promotion. Inefficiency in the allocation, utilisation, and management of health care resources is endemic. ${ }^{14}$

At this critical historic juncture the Soviet Union has a remarkable opportunity to facilitate a simultaneous development of business and public health infrastructure and formulate strategies that bridge existing values with new and adopted ones. Health Minister Chazov has identified a need for Soviet health to integrate business methods more fully and to manage health care on a commercial basis.. ${ }^{4}$ As the Soviet business sector develops, thousands of multinational corporations will compete for Soviet markets. The Soviet government will seek to ensure coordinated multisectoral social and economic development, balancing both public and private as well as domestic and international interests.

One approach might involve the emerging private 


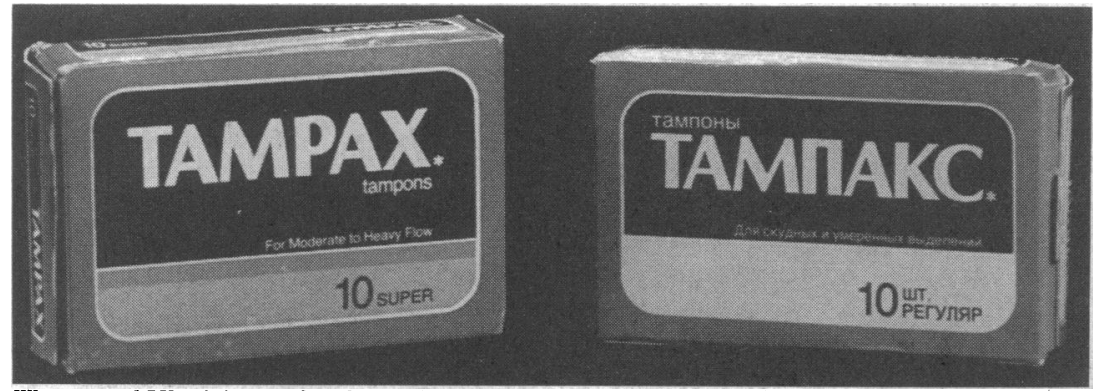

Western and Ukrainian produced tampons

and existing public sectors in strengthening and expanding public health infrastructure by utilising international joint ventures.

\section{International joint ventures in the Soviet Union}

A joint venture is a form of cooperation in which two partners share ownership of an economic undertaking, a partnership through which firms create a separate entity to carry out economic activities. ${ }^{15}$ Each party makes a substantial contribution of capital and technology, marketing skills, personnel, physical assets, and/or access to distribution networks. ${ }^{15}$ In 1986-7 the Soviet Union enacted legislation that made joint ventures possible by granting Soviet enterprises the freedom to conduct trade on their own behalf and to permit joint ventures with foreign companies on Soviet soil. This innovative departure from earlier policy enlarged East-West trading opportunities among actual and prospective Western business partners. Over 1600 foreign corporations have since registered joint venture agreements in the Soviet Union. ${ }^{15}$ In late 1988 Moscow removed the $49 \%$ ceiling on foreign ownership and in 1989 changed labour law and tax accounting to hasten the move to a market driven economy emphasising incentives, self financing, and full commercial accountability.

\section{International public health and the international joint venture}

Soviet political and economic developments may offer an opportunity for a new balance between public and private participation in public health, including strategies to link health promotion and disease prevention to economic growth ventures. As the Soviet economy is redefined it will be necessary to revise the Soviet health care system. ${ }^{4}$ Rather than model health care and preventive public health activities directly on Western models, the Soviet Union may evolve unprecedented approaches that respond specifically to Soviet realities and the opportunities created by radical economic reform. Soviet ministries should encourage international joint ventures with Western concerns that voluntarily integrate public health programmes related to the venture product or service. As the infrastructure needed to support entrepreneurial activities evolves, a low cost strengthening of public health infrastructure may be realised. Distribution networks for specific consumer products or services should be employed to target populations for disease prevention and health promotion efforts. Product education campaigns and advertising could include specific health messages. Newly acquired management skills that have proved effective in Soviet business may be applied in health. As information infrastructure in the civilian sector undergoes rapid development in a market economy linkage with product related health communications can offer dual, overlapping usages. Automotive manufacturers, for example, could collaborate with the government in establishing vehicle safety, seat belt, or child seat education programmes. Entrepreneurs in food production, services, and importing could programme nutritional education (table).

Soviet government ministries, local business, and public health can collaborate with foreign business interests to combine the cost effective, efficient management characteristic of the private sector with the equity and distributive justice of the public sector. The Soviet Union with its socialist ideological background (however unrealised) and new openness to capitalist free trade may be ideally situated to build a private-public balance that avoids the emerging gap between private and public sector health in the United States and elsewhere.

\section{Sexually transmitted diseases and unwanted pregnancy in the Soviet Union}

Sexually transmitted diseases, including AIDS, and unwanted pregnancy are serious public health problems in the Soviet Union. ${ }^{16-18}$ The magnitude of the epidemic of sexually transmitted diseases has not been quantified systematically because of limited national disease surveillance capabilities and underreporting. Until recently the Soviet government's approach to many health problems with negative social stigma has been official denial. As recently as 1988 the Soviet Union did not recognise AIDS as a national concern, ${ }^{19}$ yet evidence of a growing HIV epidemic exists. ${ }^{20}$ The average Soviet woman has three to five registered abortions in a reproductive life span. ${ }^{21}$ Official statistics report 6.2 million legally induced abortions a year, which exceeds the number of live births (roughly 5.5 million a year). ${ }^{42}$ For every registered abortion, however, it is estimated that there is at least one and possibly three unreported operations $^{21}$ (in the United States every other woman has on average a single abortion in a lifetime). Contributing to the incidence of abortion in the Soviet Union is a shortage of contraceptives.

\section{Tambrands-Ukrainian Ministry of Health joint venture}

The multinational Tambrands Inc has established an international joint venture in the Ukrainian Soviet Socialist Republic to manufacture tampons (figure).

Soviet public health needs and Western participants by programme type

\begin{tabular}{|c|c|c|}
\hline Public heaith need & Western business partner & Programme \\
\hline Injury prevention & $\begin{array}{l}\text { Automotive manufacturers and exporters, parts } \\
\text { suppliers }\end{array}$ & $\begin{array}{l}\text { Vehicle safety, seatbelt and child seat use, drunk driving } \\
\text { prevention }\end{array}$ \\
\hline $\begin{array}{l}\text { Sexually transmitted diseases } \\
\text { prevention, fertility control }\end{array}$ & $\begin{array}{l}\text { Contraceptive and pharmaceutical manufacturers } \\
\text { and exporters }\end{array}$ & $\begin{array}{l}\text { Reproductive health education, sexually transmitted diseases, } \\
\text { and unwanted pregnancy prevention }\end{array}$ \\
\hline Nutritional health education & $\begin{array}{l}\text { Food and food technology manufacturers and } \\
\text { exporters }\end{array}$ & $\begin{array}{l}\text { Cholesterol and cardiovascular health education, infant and } \\
\text { child nutrition }\end{array}$ \\
\hline $\begin{array}{l}\text { Chronic disease - primary and } \\
\text { secondary prevention }\end{array}$ & $\begin{array}{l}\text { Pharmaceutical and medical technology } \\
\text { manufacturers and exporters }\end{array}$ & $\begin{array}{l}\text { Prevention, early detection, and disability limitation for } \\
\text { various cancers, osteoarthritis, and vascular diseases }\end{array}$ \\
\hline $\begin{array}{l}\text { Substance abuse, child abuse, } \\
\text { domestic violence prevention }\end{array}$ & $\begin{array}{l}\text { Publication houses, newspaper, magazine, and } \\
\text { journalism enterprises }\end{array}$ & $\begin{array}{l}\text { Preventive health education, identification of locally accessible } \\
\text { health resources }\end{array}$ \\
\hline Dental and oral health education & $\begin{array}{l}\text { Dental technology, toothpaste, and oral product } \\
\text { manufacturers and exporters }\end{array}$ & Prevention of dental caries and periodontal disease \\
\hline
\end{tabular}


The partners are Tambrands Inc, Femtech (a Soviet counterpart incorporated as the local in-country business partner), and the Ukrainian Ministry of Health. Tambrands is providing its trademark, plant design and line equipment, training, and management. Femtech is providing labour, refined cotton, a plant site, management, and marketing. In 1990 Femtech met $3 \%$ of the demand for tampons in the Ukraine, and three additional manufacturing lines are to be assembled by late 1991 to meet $22 \%$ of demand. Tambrands will establish similar ventures in at least three other Soviet republics, with the objective of marketing union wide.

\section{Reproductive Health Education for Ukrainian Women and the Tambrands joint venture}

Reproductive Health Education for Ukrainian Women is an international health programme and private-public collaboration utilising a joint venture. The programme adapts the infrastructure thus far developed by Tambrands for the distribution of tampons in the Ukraine to institute reproductive health education for Ukrainian women on prevention of unwanted pregnancy and sexually transmitted diseases. The Ministry of Health coordinates the interaction of foreign and Soviet public health practitioners and business partners. Objectives of the programme are (a) to assess Ukrainian women's knowledge of the risks of unwanted pregnancy, including the risks associated with abortion, and reduce its incidence by contraceptive health education; $(b)$ to assess Ukrainian women's knowledge of the transmission of sexually transmitted diseases and effect changes to reduce their incidence; $(c)$ to assess factors that inhibit use of condoms; $(d)$ to establish a Soviet model for public-private collaboration in preventive health that uses international business resources and infrastructure; and (e) to expand Soviet-Western collaboration on public health issues of international importance.

Data obtained on current knowledge, attitudes, behaviours, and practices will shape culturally appropriate health education instruments. Subject recruitment and distribution of health education materials will occur by means of inserts in tampon packages. Complimentary yearlong tampon and condom supplies serve as incentives for participation. One year after distributing health education materials and condoms a repeat survey will evaluate whether high risk perceptions and behaviours have been favourably affected.

\section{Convergence of interests}

International public health collaborations utilising joint ventures converge various interests. The public health impacts in countries in need such as the Soviet Union represent an expansion of current private and public efforts. Engaging Western business interests increases health resources available to the international public. International business interests benefit from product publicity and positive public image building that results from promoting public health. For manufacturers of health products Soviet physicians who design national product education campaigns receive useful training in health education. As a Soviet private sector develops, public-private health collaboration through joint ventures offers the Soviet government the ability to integrate dynamic economic growth with continuing public sector inputs to social welfare. A fiscal benefit accrues from savings generated by the prevention of morbidity, decreased expenditure on treatment-for example, for abortion and sexually transmitted diseases - and increased economic productivity.

Seventy years of socialism and the sociocultural and political climate, however, have made it doctrinally difficult to endorse the idea of enterprise in the health sector. ${ }^{23}$ Fear of the repercussions of privatisation in health is strong among the public, physicians, and medical administrators. ${ }^{24}$ Pacing reform through public-private integration can reduce anxiety by demonstrating that private participation in health care is not tantamount to a loss of social equity and universal access. As Soviet society becomes more socioeconomically stratified in a market economy international and Soviet business contributions to public health can mitigate resentment and decrease risk of a public backlash from citizens who feel increasingly disfranchised from social advancement. International efforts to control global public health problems like sexually transmitted diseases and AIDS cannot be achieved without involving a nation of nearly 300 million (the world's third largest population). Western-Soviet collaboration to improve public health can improve international relations and ensure that the Iron Curtain remains drawn.

New opportunities exist for international public health collaboration between Western nations and the Soviet Union using the vehicle of joint business ventures. This strategy benefits the international public, governments, industry, and medical community. Western public health practitioners should take a lead in developing specific programmes linking international joint ventures to infrastructure building in Soviet health. The international medical community must demonstrate to government agencies and business interests, Soviet and Western, that not only is the promotion of good business healthy but the promotion of health is good business.

1 Anonymous. Estonia: forum medicorum Estoniae. Lancet 1989;ii:1385-6. 2 Forster DP, Jozan P. Health in eastern Europe. Lancet 1990;335:458-60. 3 Medvedev ZA. Negative trends in life expectancy in the USSR, 1964-1983. Gerontologist 1985;25:201-8.

4 Chazov E. The people's health is society's wealth. Report of the USSR minister of health at the all-union congress of physicians. Transl Oleg Svetlov. Moscow: Novosti Press Agency, 1989.

5 Gellert GA, Neumann AK, Gordon RS. The obsolescence of distinct domestic and international health sectors. F Public Health Policy 1989;10:421-4.

6 Gellert GA. Global health interdependence and the international physicians' movement. JAMA 1990;264:610-3.

7 Mover ME. A revised look at the number of uninsured Americans. Health Aff 1989;8:102-11.

8 Short PF, Monheit A, Beauregard K. Uninsured Americans: a 1987 profile. Health care technology assessment. Washington, DC: National Center for Health Services Research, 1987

9 World Health Organisation. World health statistics annual 1989. Geneva: WHO, 1989.

10 International Bank for Reconstruction and Development, World Bank. Social indicators of dezelopment 1989. Baltimore: Johns Hopkins University Press, 1989.

11 Farley P. Who are the underinsured? Milbank Memorial Fund Quarterly 1985;63:476-503

12 Rowland D, Biles B. Government. IAMA 1990;263:2646-7.

13 Silver GA. Government and health. Lancet $1988 ;$; :817-8.

14 Committee for the Study of the Future of Public Health, Division of Health Care Services, Institute of Medicine. The future of public health. Washington,
Dis. DC: National Academy Press, 1988.

15 Hall RD. The intemational joint venture. New York: Praeger, 1984.

15 Hall RD. The intermational joint venture. New York: Praeger, 1984.
16 Henshaw SK. Induced abortion: a world review, 1990. Fam Plann Perspect 1990;22:76-89.

17 De Schryver A, Meheus A. International travel and STDs. World Health Stat $Q$ 1989;42:90-9.

18 World Health Organisation. AIDS cases reported to surveillance, forecasting and impact assessment unit. Global programme on AIDS. Geneva: WHO, 1990.

9 Goldsmith MF. AIDS around the world: analyzing complex patterns. JAMA 1988;259:1917-9.

20 Gellert GA. Prevention of nosocomial HIV infection in the Soviet Union - an international responsibility. $N$ Engl f Med 1990;323:1843-4.

21 Anonymous. USSR: abortion and contraception. Lancet 1989;ii: 1208

22 Knox JDE. USSR: a pink paper. Lancet 1989;ii:732-3.

23 Ryan M. USSR letter: radical development nipped in the bud. $B M \mathcal{J}$ 1989:299:383-4.

24 Beletskava V. Novvi LiK meditsiny. Ogonyok 1988;51:20-3.

25 Parkhomovskii E. Chto govoryat spetsialisty o novom postanovlenii po kooperatsii. Izzestya 1989 January 19:2.

(Accepted 24 fanuary 1991) 